
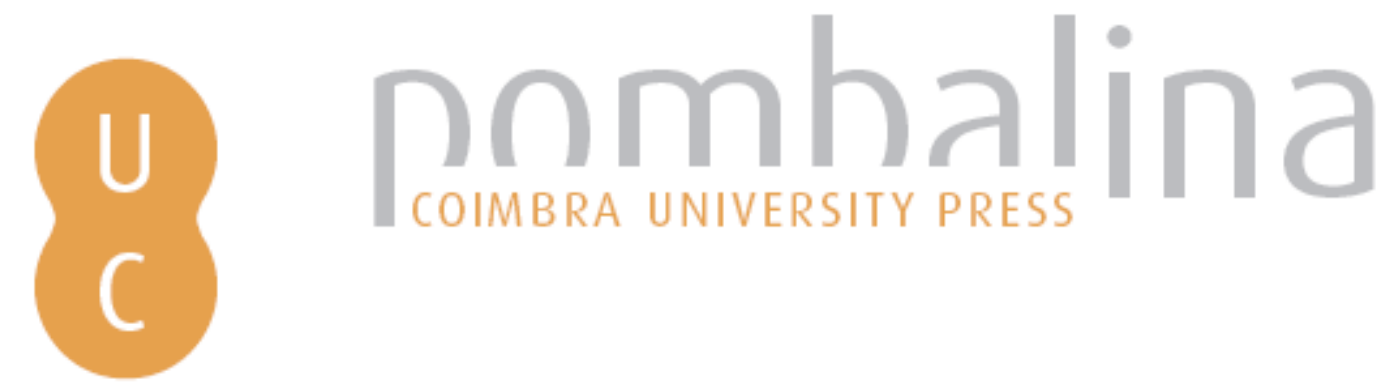

\title{
Human perception of fire hazard in wildland urban interface areas: a Portuguese survey analysis of spot fires
}

Autor(es): $\quad$ Oliveira, Ricardo; Oliveira, Sandra; Zêzere, José; Viegas, Domingos

Publicado por: Imprensa da Universidade de Coimbra

URL

persistente: URI:http://hdl.handle.net/10316.2/44643

DOI: $\quad$ DOI:https://doi.org/10.14195/978-989-26-16-506_126

Accessed : $\quad$ 26-Apr-2023 16:28:24

A navegação consulta e descarregamento dos títulos inseridos nas Bibliotecas Digitais UC Digitalis, UC Pombalina e UC Impactum, pressupõem a aceitação plena e sem reservas dos Termos e Condições de Uso destas Bibliotecas Digitais, disponíveis em https://digitalis.uc.pt/pt-pt/termos.

Conforme exposto nos referidos Termos e Condições de Uso, o descarregamento de títulos de acesso restrito requer uma licença válida de autorização devendo o utilizador aceder ao(s) documento(s) a partir de um endereço de IP da instituição detentora da supramencionada licença.

Ao utilizador é apenas permitido o descarregamento para uso pessoal, pelo que o emprego do(s) título(s) descarregado(s) para outro fim, designadamente comercial, carece de autorização do respetivo autor ou editor da obra.

Na medida em que todas as obras da UC Digitalis se encontram protegidas pelo Código do Direito de Autor e Direitos Conexos e demais legislação aplicável, toda a cópia, parcial ou total, deste documento, nos casos em que é legalmente admitida, deverá conter ou fazer-se acompanhar por este aviso.

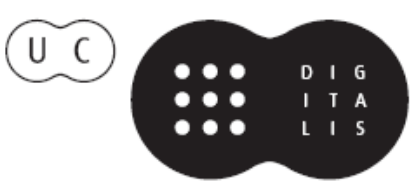




\section{ADVANCES IN}

\section{FOREST FIRE RESEARCH}

\section{8}

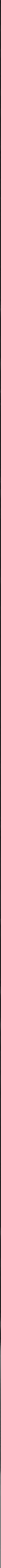




\title{
Human perception of fire hazard in wildland urban interface areas - a Portuguese survey analysis of spot fires
}

\author{
Ricardo Oliveira*1; ${ }^{1}$ Sandra Oliveira ${ }^{2}$; José Zêzere ${ }^{2}$; Domingos Viegas ${ }^{1,3}$ \\ ${ }^{1}$ Forest Fire Research Centre (CEIF), ADAI-LAETA, University of Coimbra, 3030 - 289 Coimbra, \\ Portugal, \{ricardo@adai.pt*\} \\ ${ }^{2}$ Instituto de Geografia e Ordenamento do Território; Universidade de Lisboa - Lisboa, Portugal, \\ ${ }^{3}$ FCTUC; Departamento de Engenharia Mecânica - Coimbra, Portugal.
}

\begin{abstract}
Nowadays, wildfires are the most devastating natural hazard in Portugal with the highest number of victims and mortality of both operational agents and civilians. During the yearly Wildfire Season, which is determined by law from 15th of May until 15th of October, extra efforts are carried out by the civil protection through dedicated financial and human resources. In the recent years, most of the available resources were employed with their highest capacities in Portugal to control wildland fires. However, still, a high number of fires escape first attach and results in large fires (>100 ha). On the years 2012, 2013, 2016 and 2017 there is temporal variances appeared in the recorded ignitions, where high ignitions recorded during the spring and some of them developed in large and deadly wildfires like the fires ignited in 17th of June 2017 in the Centre of Portugal with 65 mortalities. In the autumn of the same year as well, 2017, large fires were ignited in 15th of October 2017 with 47 mortalities. In 2015, the Institute for Conservation of Nature and Forests (ICNF) recorded a total of 15851 occurrences, the National Republican Guard investigated $76 \%$ of those and identified $47 \%$ of them occurred due to negligent human behaviour. $89 \%$ of these occurrences are due to leftover burnings. With such a high number of anthropogenic causes, there is a need arises to evaluate the human perception of wildfires hazards, particularly in Wildland-Urban Interfaces (WUI). The evaluation will assist in reducing the occurrences due to negligent behaviours, which is the aim of this study in addition to highlighting the needed awareness actions based on that perception. As a methodology, we defined territories in Mainland Portugal recently affected by wildfires; then we characterised them based on human and physical aspects. A survey with 40 questions was generated. We divided the survey into four sections according to the purpose of the questions, which are sociographic characterisation; perception of the participant regarding the wildfire hazard; the impact of wildfire in the area of the participant; and finally, the participant suggestion of mitigation and prevention measures. The query was pre-tested first by selecting a small population group formed of 30 residents, which is in Algeriz, located in the district of Aveiro. As some preliminary results, a pre-test showed that $85.2 \%$ of the sample addressed wildfires as the most significant natural hazard impacting his/her life, followed by floods. $3.7 \%$ of the participants reported that they suffered from housing damage due to wildfires To complete our understanding of the people perception of wildfire hazards, this survey will be extended to several other territories of Portugal Mainland, and analyse the patterns of answers.
\end{abstract}

Keywords: wildfire, impact, perception, survey, spot fire

\section{Introduction}

Wildfires are the most devastating environmental hazard in Portugal, with the highest number of victims and mortality of both operational agents and civilians, and causing severe economic and environmental consequences (Oliveira et al., 2017) (Nunes et al., 2016) (San-Miguel-Ayanz et al., 2013) (Tedim et al., 2015) (Turco et al., 2016). Most fires in Portugal result from human activities, with negligence associated with leftover burning as the primary cause (ICNF, 2016a). The year of 2017 was particularly severe, with 112 fatal victims and a total burned area in the country of around 500.000 ha (ICNF, 2017). The temporal trends of wildfire occurrence during this year indicate that the larger fires, that caused higher losses, occurred in late spring (June) and autumn (October). In Portugal,

Advances in Forest Fire Research 2018 - Page 1130 
the main wildfire season is established by Law and extends from $15^{\text {th }}$ May to $15^{\text {th }}$ October; during this period, an extra effort is carried out by the civil protection services through additional financial and human resources, and most fires are controlled in the early stages of development (Diário da República, 2006). However, a certain number of fires still escape control during the early attack by suppression resources and may result into fires above 500 ha in size. When driven by favorable weather conditions, in places with irregular topography and higher slopes, these fires exhibit extreme and unexpected behaviour and escape the control of suppression resources (Viegas et al., 2017).

The tragic situation verified in Central Portugal in 2017 also derived from other characteristics of the territory, in particular the dispersion of small settlements interspersed in wildland areas, where fuels accumulated due to the abandonment of agricultural activities in the last decades (Nunes et al., 2016) (Moreira et al., 2011)(San-Miguel-Ayanz et al., 2012). These areas, generally defined as Wildland-Urban Interface (WUI), have been the focus of multiple studies regarding wildfire mitigation, since the coexistence of vegetated areas with human structures and potential ignition agents increase risk levels (Modugno et al., 2016) (Badia et al., 2011).

\subsection{Spot fires}

According to the conditions of propagation, fires are divided in four types: surface fires, crown fires, ground fires and spot fires (Almeida, 2011). Spot fires are caused by the projection of sparks or embers at a distance from the main fire and are a characteristic of extreme wildfire behavior (Viegas, 2012) (Almeida et al., 2014). Previous studies indicate a direct relation between damages in buildings and spot fires, with damages resulting from the direct contact with a fire front being rarer (Cohen, 2010) (Blanchi \& Leonard, 2008) (Caballero, 2017).

Research on spot fires and their relation with wildfire behavior dates back from the fifties of the last century (Byram, 1954) (McArthur, 1967) (Lee \& Hellman, 1969); however, several knowledge gaps still remain, mainly regarding the difficulty in determining with high accuracy the amount, size, shape and landing spot of burning particles, as well as their ability to ignite a new fire. As such, the results of this thematic research are usually reflected in guidelines and good practices to help mitigating the effects of spot fires in human structures, through fuel management options and in the involvement of communities in decision-making.

Considering the strong human dimension of fire causes, the characteristics of the WUI, the relevance of spot fires in wildfire behavior and the severe impacts of wildfires in the country, it is crucial to understand how people perceive fire occurrence in their area of residence and their knowledge on spot fires as a means of fire propagation in extreme conditions. This study aimed to evaluate people's perception of spot fires in wildland-urban interface areas, in order to identify potential mitigation and prevention (awareness) actions based on their knowledge, experience and needs.

\section{Materials and methods}

\subsection{Study area}

This study was carried out in two test areas of mainland Portugal that were recently affected by wildfires: Algeriz (Vila Nova (VN) de Monsarros - Anadia) in 2016 and Pedrógão Grande in 2017 (Figure ).

Area 1 - Algeriz. Village located in the countryside of the civil parish of Vila Nova de Monsarros, in the municipality of Anadia, Aveiro district (Figure ). According to the latest Census Survey 2011 (INE, 2012), the municipality of Anadia has 29150 residents, distributed by 10 civil parishes and a population density of 134,58 people/ $\mathrm{km}^{2}$. The civil parish of VN Monsarros occupies an area of 23,72 $\mathrm{km}^{2}$ and has 1713 inhabitants, with a population density of 72,2 people/ $\mathrm{km}^{2}$, lower than the municipal average. In Algeriz village, currently live 30 people. 
This municipality was affected by a wildfire that started on 10 August 2016, with a burned area extending for 2538,9 ha, which corresponds to $11.7 \%$ of the municipality area. The civil parish of VN Monsarros by itself contributed with 1691 ha, corresponding to $71.29 \%$ of its total area.

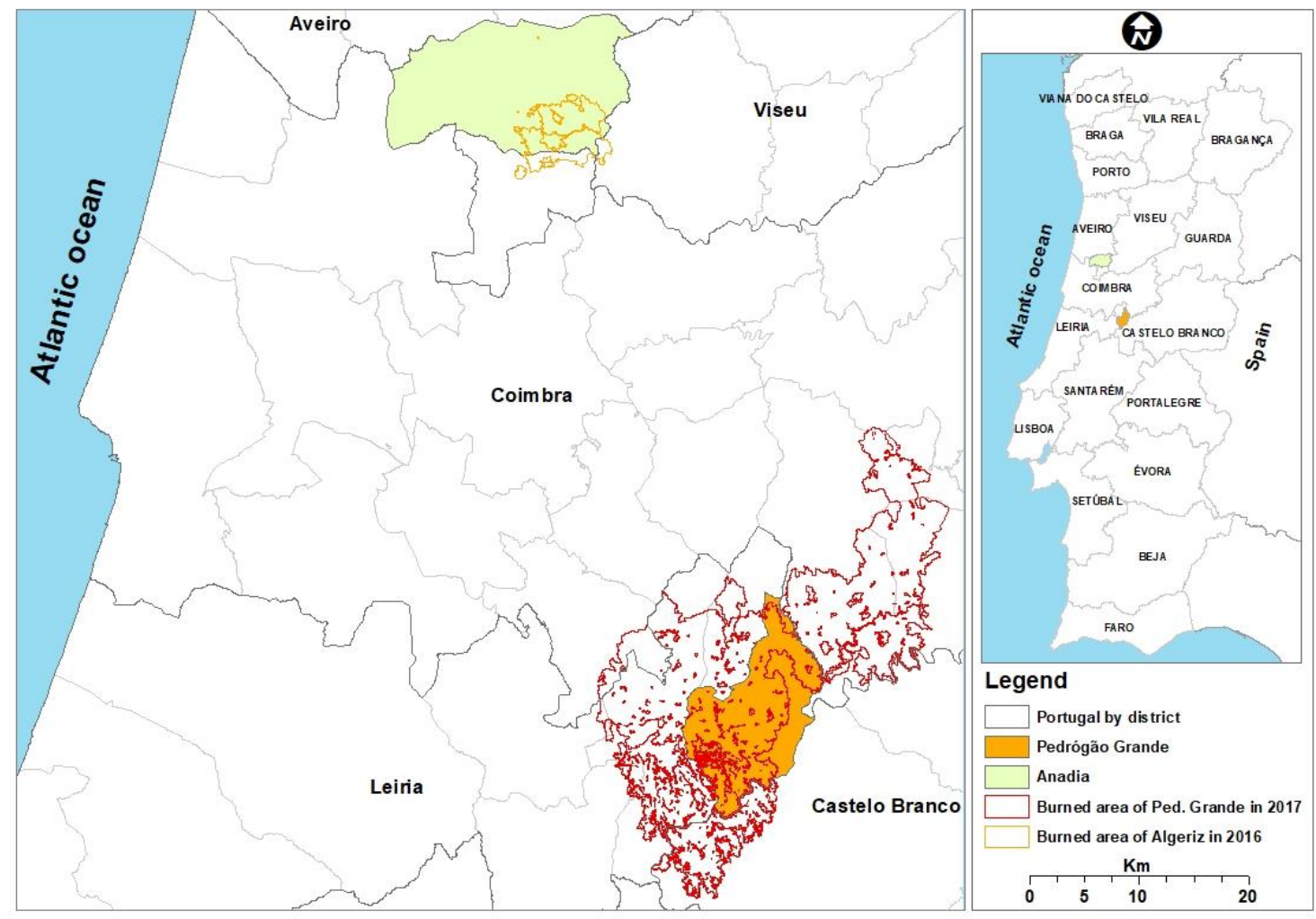

Figure 1 - Location of the two test areas

The cause of the fire has supposedly been the contact between a fallen electric line in a steep slope and the vegetation, mainly composed of eucalyptus, under windy conditions (ICNF, 2016b).

Area 2 - Pedrógão Grande is a municipality located in the district of Leiria, in the Central Region. It has an area of 128,75 $\mathrm{km}^{2}$ and 3915 residents (INE, 2012), divided in 3 civil parishes. The population density corresponds to 30,4 people $/ \mathrm{km}^{2}$, much lower than the national average of 114,5 people $/ \mathrm{km}^{2}$ and less than half of the population density of VN Monsarros.

This municipality was severely affected by a wildfire that started on 17 June 2017, with a burned area extending for $9407,6 \mathrm{ha}$, corresponding to $73.06 \%$ of the municipality area (Viegas et al., 2017). The probable cause of the fire has been identified as the contact between an electric line and the canopy of a cork oak tree, in dry and windy weather conditions (Viegas et al., 2017).

\subsection{Data collection - survey questionnaire}

Data on prior experience and perception of wildfire occurrence by residents was obtained through the implementation of a survey questionnaire in the test areas. In total, 47 questionnaires were made face-to-face.

The questionnaire was composed of 40 questions, divided into 4 sections:

i. The first section included questions regarding the individual characteristics of people (age, gender, nationality, place of origin, education level and occupation). Additionally, the relation of people with forest activities and prior experience with wildfires were also included;

ii. The second section comprised essentially the conceptual understanding of wildfire risk, spot fires and wildland-urban interface areas; 
iii. The third section focused on the prior experience of people with different wildfire impacts and their knowledge on propagation conditions related to construction and property;

iv. The fourth section included questions about the knowledge and preferences of people regarding wildfire prevention and mitigation measures.

This paper focuses mainly on the results obtained with sections 1 and 2 of the questionnaire.

\subsection{Data analysis}

The personal characteristics and wildfire experience of the interviewees, compiled in section 1 of the questionnaire, were first analyzed with descriptive statistics, to uncover the overall sociodemographic context of the respondents. These characteristics were subsequently tested for association with the responses given in the second section, regarding the understanding of several wildfire-related concepts. To attain this goal, the Pearson $\chi^{2}$ (chi-square) test was applied to multiple pairs of questions. This test measures the difference between the observed values in each category and the expected values, which should be similar among categories if no significant association exists (Scheffe, 1959). For open-ended questions, to which no prior option was provided and where the responses were based on the individual's own knowledge or experience, a data-driven analysis based on text mining techniques was applied. These techniques allow to explore the frequency of specific terms, the relation between different words and to visualize graphically the most common words that people associate with the question posed (with word clouds, for example). These results were used to define particular categories of responses retrieved from the open-ended questions, for further analysis regarding their association with personal characteristics and prior wildfire experience. The statistical analysis of the questionnaire responses was made with the R software (R Project for Statistical Computing) (Bunn \& Korpela, 2016), to create automatic routines and to enable the replication of the analysis procedure in other areas and with new data.

\section{Results and discussion}

Initial results showed that $64 \%$ of the participants were women, $79 \%$ were above 50 years old and $52 \%$ had no education level or only the elementary school (Erro! A origem da referência não foi encontrada.). About $96 \%$ of the interviewed people were previously affected by wildfires and only $11 \%$ have a job related to forest activities (Table 1).
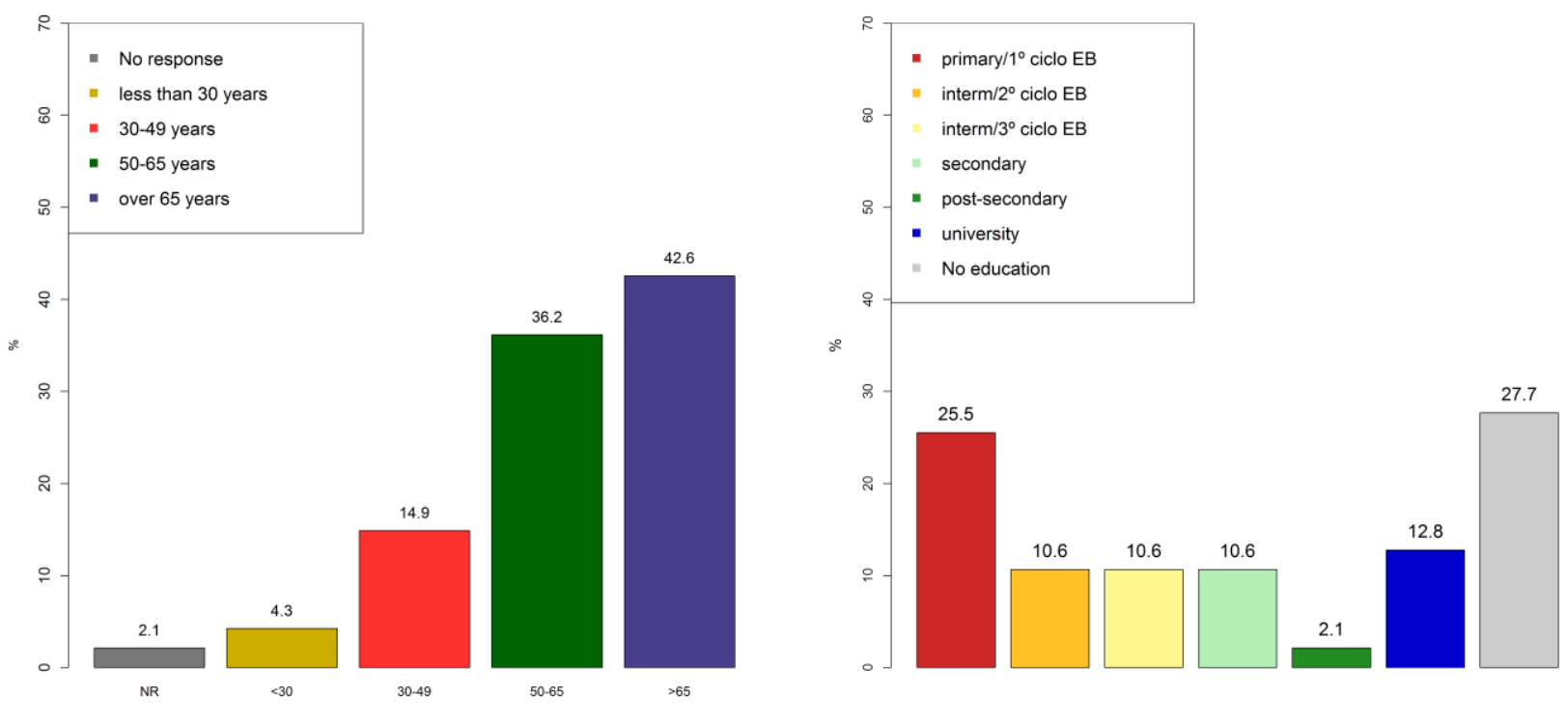

Figure 2 - Proportion of people by age groups (left) and by education level (right) 
Table 1-Percentage of people with regards to residency, professional status and job related to forest

\begin{tabular}{|l|c|l|c|l|c|}
\hline $\begin{array}{c}\text { Resident in the parish } \\
\text { of origin }\end{array}$ & \multicolumn{2}{c|}{ Professional status } & \multicolumn{2}{c|}{ Job related to forest } \\
\hline Categories & $\%$ & Categories & $\%$ & Categories & $\%$ \\
\hline Yes & 85.1 & Employed & 46.8 & Yes & 10.7 \\
No & 14.8 & Unemployed & 8.5 & No & 89.3 \\
& & Retired & 44.7 & & \\
\hline
\end{tabular}

These personal characteristics and experience showed association with the responses given in section 2. The concept of wildfire risk was different depending on age groups, education level and professional status (Table ). Regarding age groups, people above 65 years old answered mostly that they didn't know, or didn't want to answer (80\%), whereas only $14 \%$ of people below 50 years old didn't give an answer. The majority of people who responded mentioned that wildfire risk is not probability, weather conditions nor fuel management, giving a wide diversity of opinions that are difficult to classify ("Others"). Regarding education levels, the proportion of people that responded didn't know/respond was higher for people with no education $(85 \%)$ or people with elementary school level $(58 \%)$. The relation of wildfire risk with Probability was mostly selected by people with university level $(33 \%)$ and by people with secondary education (20\% of the total people in this level). In relation to the professional status, for the people who are currently employed (47\%), $18 \%$ relate wildfire with Probability, $14 \%$ with Risk, $5 \%$ with weather conditions, $5 \%$ with lack of fuel management and $45 \%$ relate it to other conditions. Retired people correspond to $45 \%$ of the interviewees and the majority answered, "didn't know/respond" (76 \%).

Table 2 - Association between personal characteristics and the answers given in section 2 of the survey

Q10 - What is wildfire risk?

\begin{tabular}{|l|c|c|c|}
\hline Characteristics \& Experience & $\chi 2$ & $p$-value & df \\
\hline Age groups & 36,39 & 0,0138 & 20 \\
\hline Education level & 46,03 & 0,0308 & 30 \\
\hline Professional status & 22,14 & 0,0144 & 10 \\
\hline
\end{tabular}

Q11 - How do you classify your knowledge on wildfire risk?

\begin{tabular}{|l|c|c|c|}
\hline Characteristics \& Experience & $\chi 2$ & $p$-value & $\mathrm{df}$ \\
\hline Job related to forest & 18,16 & 0,0004 & 3 \\
\hline
\end{tabular}

Q12 - Do you know what are spot

fires?

\begin{tabular}{|l|c|c|c|}
\hline Characteristics \& Experience & $\chi 2$ & $p$-value & df \\
\hline Job related to forest & 8,66 & 0,0131 & 2 \\
\hline
\end{tabular}

Q20 - Do you think you can defend yourself, your family and your property against wildfires?

\begin{tabular}{|l|c|c|c|}
\hline Characteristics \& Experience & $\chi 2$ & $p$-value & df \\
\hline Education level & 27,60 & 0,0063 & 12 \\
\hline Previously affected by fires & 6,46 & 0,0393 & 2 \\
\hline
\end{tabular}

$\chi^{2}$ - value of the Pearson $\chi^{2}$ test; $p$-value indicates significance of the association; if the p-value is less than 0.05, the difference in the responses related to the personal characteristic tested is significant at $95 \%$ level. $d f$-degrees of freedom 
The level of knowledge on wildfire risk and spot fires activity (Question 11) is associated with having a job related to forest or not; from those people who don't work in forest activities $(90 \%)$, the majority says their knowledge is low $(64 \%)$, whereas the people with forest-related activities (10\%) mostly gave the answer "Doesn't know/respond" (66\%) and none said their knowledge was high. This may be related to their age and education level, since most of the people with forest-related activities are above 60 years old. Regarding spot fires (Question 12), about $56 \%$ of the people who don't work in forest activities said they know what they represent, which means that this knowledge may be disseminated through other sources, eventually by past experiences.

Regarding the possibility of self-defense (Question 20), $92 \%$ of the people with no education mention they can't protect themselves properly; on the other hand, most of the people with secondary and university education levels also said they had no conditions for self-protection $(80 \%$ and $83 \%$, respectively). These results can be related to the lack of fire experience of the younger and more educated population, whose relation with fire is different from older generations.

\section{Further work}

To deepen our understanding on the perception of wildfire occurrence in the country, this survey is being extended to several other areas in the Portuguese mainland. The responses will be analyzed with the same procedure to further explore the relationship between personal characteristics and prior experience with wildfire knowledge of wildfires. These results can contribute to improve educational programmes dedicated to students in schools; furthermore, prevention and mitigation options can be adapted to the needs and experience of people who live in wildland-urban interface areas, in order to improve wildfire awareness.

\section{References}

Almeida, M. A. de F. B. de. (2011). Propagação de incêndios florestais por focos secundários. Retrieved from https://estudogeral.sib.uc.pt/handle/10316/16441

Almeida M. Viegas D. X. Raposo J. (2014). Analysis of firebrand release on the spot fire mechanism. In AdvAnces in Forest Fire reseArch (pp. 4-6). Coimbra.

Badia, A., Serra, P., \& Modugno, S. (2011). Identifying dynamics of fire ignition probabilities in two representative Mediterranean wildland-urban interface areas. Applied Geography, 31(3), 930-940. https://doi.org/10.1016/j.apgeog.2011.01.016

Blanchi, R., \& Leonard, J. (2008). The influence of human behaviour on house loss, 2008.

Bunn, A., \& Korpela, M. (2016). Crossdating in dplR, 2, 1-12. https://doi.org/10.1016/j.dendro.2009.12.001

Byram, G. M. (1954). Atmospheric conditions related to blowup fires. Station Paper SE-SP-35. Asheville, NC: USDA-Forest Service. Southeastern Forest Experiment Station., 36.

Caballero, D. (2017). Wildland-Urban Interface Forest Fire Risk Observatory and Interest Group in Europe WUIWATCH Agreement № ECHO/SUB/2014/694556.

Cohen, J. (2010). The wildland-urban interface fire problem. Fremontia, 38(2), 16-22. https://doi.org/10.1071/WF07131

Diário da República. (2006). Decreto-Lei 124/2006 de 28 de Junho. Diário Da República, $1^{a}$ Série $A\left(\mathrm{~N}^{\mathrm{O}} \quad\right.$ 123), 4586-4599. $\quad$ Retrieved from https://dre.pt/application/dir/pdf1sdip/2006/06/123A00/45864599.pdf

Domingos Xavier Viegas, Miguel Figueiredo Almeida, Luís Mário Ribeiro, Jorge Raposo, Maria Teresa Viegas, Ricardo Oliveira, Daniela Alves, Cláudia Pinto, Jorge Humberto, André Rodrigues, Davi Lucas, Sérgio Lopes, Luís Filipe Silva. (2017). O complexo de incêndios de Pedrógão Grande e concelhos limítrofes, iniciado a 17 de junho de 2017. Retrieved from 
https://www.portugal.gov.pt/download-ficheiros/ficheiro.aspx?v=3bb9773b-59fb-4099-9de5a22fdcad $1 \mathrm{e} 3 \mathrm{~b}$

ICNF. (2016a). RELATÓRIO ANUAL DE ÁREAS ARDIDAS E INCÊNDIOS FLORESTAIS EM PORTUGAL CONTINENTAL.

ICNF. (2016b). Relatório de estabilização de emergência - INCÊNDIO FLORESTAL DE ALGERIZ.

ICNF. (2017). 10. RELATÓRIO PROVISÓRIO DE INCENDIOS FLORESTAIS - 201701 DE JANEIRO A 31 DE OUTUBRO. Lisboa.

Instituto Nacional de Estatística. (2012). Censos 2011 Resultados Definitivos. Censos 2011, 26, 1-41. https://doi.org/ISBN 978-989-25-0148-2

Lee, S.L., \& Hellman, J. M. (1969). Study of firebrand trajectories in a turbulent swirling natural convection plume. Combustion and Flame, 13(6), 645-655. https://doi.org/10.1016/00102180(69)90072-8

McArthur A. (1967). Fire behaviour in eucalypt forests., (107), 144.

Modugno, S., Balzter, H., Cole, B., \& Borrelli, P. (2016). Mapping regional patterns of large forest fires in Wildland-Urban Interface areas in Europe. Journal of Environmental Management, 172(July), 112-126. https://doi.org/10.1016/j.jenvman.2016.02.013

Moreira, F., Rego, F. C., \& Ferreira, P. G. (2001). Temporal (1958 - 1995) pattern of change in a cultural landscape of northwestern Portugal : implications for fire occurrence. Landscape Ecology, 2(Ccrn 1995), 557-567. https://doi.org/10.1023/a:1011169614489

Moreira, F., Viedma, O., Arianoutsou, M., Curt, T., Koutsias, N., Rigolot, E., Bilgili, E. (2011). Landscape - wildfire interactions in southern Europe: Implications for landscape management. Journal of Environmental Management, 92(10), 2389-2402. https://doi.org/10.1016/J.JENVMAN.2011.06.028

Nunes, A. N., Lourenço, L., \& Meira, A. C. C. (2016). Exploring spatial patterns and drivers of forest fires in Portugal (1980-2014). Science of The Total Environment, 573, 1190-1202. https://doi.org/10.1016/J.SCITOTENV.2016.03.121

Oliveira, S., Zêzere, J. L., Queirós, M., \& Pereira, J. M. (2017). Assessing the social context of wildfire-affected areas. The case of mainland Portugal. Applied Geography, 88, 104-117. https://doi.org/10.1016/j.apgeog.2017.09.004

San-Miguel-Ayanz, J., Marcos Rodrigues Q., Oliveira S.,Pacheco C.K., Moreira F., Duguy B., C. A. (2012). Land Cover Change and Fire Regime in the European Mediterranean Region. Chapter 2, In: Post-Fire Management and Restoration of Southern European Forests, 2012 Edited by Moreira F., Arianoutsou M., Corona P. De Las Heleras J., 02/2012: Chapter Land Cover Change and Fire Regime in the European Mediterranean Region: Pages 21-43;, 24(102162), 2012.

San-Miguel-Ayanz, J., Moreno, J. M., \& Camia, A. (2013). Analysis of large fires in European Mediterranean landscapes: Lessons learned and perspectives. Forest Ecology and Management, 294, 11-22. https://doi.org/10.1016/J.FORECO.2012.10.050

Scheffe, H. Y. (1959). The Analysis of Variance.

Tedim, F., Xanthopoulos, G., \& Leone, V. (2015). Forest Fires in Europe: Facts and Challenges. Wildfire Hazards, Risks and Disasters, 77-99. https://doi.org/10.1016/B978-0-12-4104341.00005-1

Turco, M., Bedia, J., Di Liberto, F., Fiorucci, P., Von Hardenberg, J., Koutsias, N., ... Provenzale, A. (2016). Decreasing fires in mediterranean Europe. PLoS ONE, 11(3). https://doi.org/10.1371/journal.pone.0150663

Viegas, D. X. (2012). EXTREME FIRE BEHAVIOUR. LAETA-ADAI Departamento de Engenharia MecâNica Da Universidade de Coimbra, 56. 